\title{
Monitoring of lead in the environment
}

\author{
I. B. MILLAR \\ From the Greenwich Health District, London
}

SUMMARY Children living near a lead works and children of employees at the works were selected in order to analyse the lead content of their blood as the biological counterpart of a monitoring exercise for lead in the environment. The overall mean for the 262 children in the survey was 0.91 $\mu \mathrm{mol} / \mathrm{l}$ and results were within the normal reference range of 0.3 to 1.8 for all except two children. The results compared favourably with similar areas, and with a survey in the same area in 1972. The mean for the 71 children of employees at the lead works was $1.02 \mu \mathrm{mol} / \mathrm{l}$, significantly higher than the mean for the other children in the survey $(0.88 \mu \mathrm{mol} / \mathrm{l})$. No appreciable differences were found in housing or wind direction. The means for all groups were unexceptional, but some of the differences were significant. Younger children had significantly higher blood lead levels than older children, and the group of 26 children with levels of $1.3 \mu \mathrm{mol} / 1$ or more was doubly weighted with the youngest age group. After careful investigation, no deviations from normal health were found in this group. The weighting of younger children also contributed to the significance of the higher mean found for children living in the central half of the area.

\section{Introduction}

In 1971 the Chief Medical Officer of the Department of Health and Social Security advised Medical Officers of Health to review areas of potential lead hazard within their districts. In the London borough of Greenwich an area containing a lead works was selected for investigation.

This works has existed on its present site for about 40 years. Its operations include rotary smelting furnaces, ancillary plant and cable burning furnaces, and a refinery for the production of lead and lead alloys. Houses have been built on three sides of the factory, most recently in the London borough of Bexley, adjoining Greenwich. On its southern flank alone, the streets are of an earlier period. The possibility of exposure to lead was clearly a matter of concern to the public as well as the employees. A survey of the atmosphere surrounding the factory was carried out by agreement between officers of the London boroughs of Greenwich and Bexley, the Alkali and Clean Air Inspectorate, the Greater London Council Scientific Branch, the Factory Inspectorate, and the company.

Samples of dust and soil were collected from 44 sites (28 in Greenwich, 16 in Bexley). First results indicated levels of contamination higher than expected in the general atmosphere, but not appreciably different from those at comparable sites elsewhere. Not surprisingly, the higher levels were at the entrance to the works.
The company, anxious to keep down pollution, undertook to put in hand without delay all the improvements required by the district Alkali and Clean Air and Factory Inspectors. It was also thought desirable to investigate the blood lead levels in children living near the works. In 1972, blood samples from 65 pre-schoolchildren were tested, but all were within acceptable limits. The mean of the results was the equivalent of $1 \cdot 3 \mu \mathrm{mol} / \mathrm{l}$. Employees' children were also offered the test, but the response was disappointing. The results for these children were all within acceptable limits. Their mean was equivalent to $1.6 \mu \mathrm{mol} / 1$.

In 1973 the results obtained from lead deposit gauges at certain points still indicated contamination above the normal level. Analyses of flue emission were satisfactory, and this led to the conclusion that the contamination was mainly dustborne. Once again the company accepted and acted upon advice to introduce a series of measures designed to reduce the amount of dust. Throughout the investigation, no evidence came to light that the health of the inhabitants living in the locality of the works was being endangered by base metal atmospheric pollution; nevertheless, because of intermittent high deposit levels in close proximity to the works, monitoring continued. Early in 1976 a working party was formed and it was decided to repeat blood lead tests on children and to extend them if possible to a greater number of children and to a wider age range. 
The 1976-77 blood lead survey

It was agreed that blood tests should be offered to about 200 Greenwich and Bexley children up to the age of 16 living within approximately $\mathbf{4 0 0}$ metres of the lead works, and also, if possible, to the same number of children of employees at the works. The aim was to select children evenly by age, sex, and street throughout the area, except for employees' children, many of whom lived elsewhere. It was decided to use the capillary method of blood sampling as a first choice, keeping venepuncture in reserve when necessary. The blood analyses were carried out at the Department of Chemical Pathology of the Institute of Child Health, using a normal reference of 0.3 to $1.8 \mu \mathrm{mol} / \mathrm{l}$. The Delves' cup method with atomic absorption spectrophotometry was used (Delves, 1970). The number of samples taken was 352, but analysis of the first batch revealed spoilage due to contamination of some samples with the ordinary background lead. In spite of the careful preparations that were made to prevent this from happening, the degree of spoilage ruled out further testing, and the parents had to be offered repeat sampling by venepuncture for their children. Three-quarters of the repeat invitations were accepted, and 262 blood samples were taken by this method. Of this total, 191 samples were from children living in the survey area (hereafter described as community children) and 71 were from the children of employees, some of whom lived in the survey area. The loss of 90 participants did not appreciably alter the proportional distribution of the 262 children.

\section{Results}

The results of the analyses are set out by age and sex in Table 1 for community children and in Table 2 for employees' children.
All except two of the results were within the normal reference range and the overall mean for the 262 children was $0.91 \mu \mathrm{mol} / 1$ with a standard deviation of $0 \cdot 2755$. This was below the mid-point of the normal reference range. The mean for community children was $0.88 \mu \mathrm{mol} / 1$ with a standard deviation of 0.26 , and the mean for employees' children was $1.02 \mu \mathrm{mol} / 1$ with a standard deviation of $\mathbf{0 . 3 0}$. This difference is statistically significant, being over three times its standard error (Table 3c) and it is similar to the difference found in Manchester (Elwood et al., 1977). The distribution of these results, represented by the Figure, compares favourably with the biological quality guide for standards in the European Economic Community (Zielhuis, 1974).

Table 3 Significance of differences in means between various groups

\begin{tabular}{|c|c|c|c|}
\hline & \multicolumn{3}{|c|}{ (a) Between age groups } \\
\hline & umol/l & $\chi^{2}$ & $\boldsymbol{P}$ \\
\hline $\begin{array}{l}0-4 \text { and 5-16 } \\
\text { Community children } \\
\text { Employees' children }\end{array}$ & $\begin{array}{l}0.174 \\
0.349\end{array}$ & $\begin{array}{l}3 \cdot 72 \\
3 \cdot 46\end{array}$ & $\begin{array}{l}<0.001 \\
<0.001\end{array}$ \\
\hline $\begin{array}{l}\text { 5-10 and } 11-16 \\
\text { Community children } \\
\text { Employees' children }\end{array}$ & $\begin{array}{l}0.135 \\
0.222\end{array}$ & $\begin{array}{l}3 \cdot 55 \\
3 \cdot 76\end{array}$ & $\begin{array}{l}<0.001 \\
<0.001\end{array}$ \\
\hline
\end{tabular}

Community children

0- 4

$5-10$
$11-16$

All

(b) Between sexes

Employees' children

5-10

0.086

$0 \cdot 086$
$0 \cdot 057$
0.112

$0 \cdot 112$

$\mathbf{0 . 8 1}$

$0 \cdot 73$
$2 \cdot 14$

0.082

$2 \cdot 24$

NS
$<\mathbf{0 . 0 5}$

$<0.05$

$0 \cdot 126$

$0 \cdot 167$

$0 \cdot 22$
$2 \cdot 2$

NS

All

$0 \cdot 114$

$2 \cdot 37$

$<0.05$

(c) Between community children and employees' children

\begin{tabular}{rlll}
$0-4$ & 0.305 & 2.24 & $<0.05$ \\
$5-10$ & 0.178 & 3.85 & $<0.001$ \\
$11-16$ & 0.091 & 1.9 & $<0.1$ \\
All & 0.137 & 3.65 & $<0.001$ \\
\hline
\end{tabular}

Table 1 Blood lead levels by age and sex of community children living within approximately 400 metres of the lead works

\begin{tabular}{|c|c|c|c|c|c|c|c|c|c|}
\hline $\begin{array}{l}\text { Age group } \\
\text { (years) }\end{array}$ & Boys & $\begin{array}{l}\text { Mean } \\
\mu m o l / l\end{array}$ & $S D$ & Girls & $\begin{array}{l}\text { Mean } \\
\text { umolll }\end{array}$ & $S D$ & $\begin{array}{l}\text { Total } \\
\text { children }\end{array}$ & $\begin{array}{l}\text { Mean } \\
\text { umol/l }\end{array}$ & $S D$ \\
\hline $\begin{array}{r}0-4 \\
5-10 \\
11-16\end{array}$ & $\begin{array}{l}18 \\
55 \\
25\end{array}$ & $\begin{array}{l}1.061 \\
0.918 \\
0.812\end{array}$ & $\begin{array}{l}0.35 \\
0.22 \\
0.19\end{array}$ & $\begin{array}{l}16 \\
51 \\
26\end{array}$ & $\begin{array}{l}0.975 \\
0.861 \\
0.7\end{array}$ & $\begin{array}{l}0.26 \\
0.26 \\
0.19\end{array}$ & $\begin{array}{r}34 \\
106 \\
51\end{array}$ & $\begin{array}{l}1.02 \\
0.89 \\
0.755\end{array}$ & $\begin{array}{l}0.31 \\
0.24 \\
0.19\end{array}$ \\
\hline All & 98 & 0.917 & 0.25 & 93 & 0.835 & $0 \cdot 26$ & 191 & 0.878 & 0.26 \\
\hline
\end{tabular}

Table 2 Blood lead levels by age and sex of lead works employees' children

\begin{tabular}{|c|c|c|c|c|c|c|c|c|c|}
\hline $\begin{array}{l}\text { Age group } \\
\text { (years) }\end{array}$ & Boys & $\begin{array}{l}\text { Mean } \\
\text { umolll }\end{array}$ & $S D$ & Girls & $\begin{array}{l}\text { Mean } \\
\text { umol/l }\end{array}$ & $S D$ & $\begin{array}{l}\text { Total } \\
\text { children }\end{array}$ & $\begin{array}{l}\text { Mean } \\
\text { umol/l }\end{array}$ & $S D$ \\
\hline $\begin{array}{r}0-4 \\
5-10 \\
11-16\end{array}$ & $\begin{array}{r}5 \\
18 \\
9\end{array}$ & $\begin{array}{l}1.36 \\
1.061 \\
0.955\end{array}$ & $\begin{array}{l}0 \cdot \overline{26} \\
0 \cdot 22\end{array}$ & $\begin{array}{r}3 \\
19 \\
17\end{array}$ & $\begin{array}{l}1 \cdot 266 \\
1.074 \\
0.788\end{array}$ & $\begin{array}{l}0 . \overline{25} \\
0.16\end{array}$ & $\begin{array}{r}8 \\
37 \\
26\end{array}$ & $\begin{array}{l}1 \cdot 325 \\
1.068 \\
0.846\end{array}$ & $\begin{array}{l}0.48 \\
0.25 \\
0.20\end{array}$ \\
\hline All & 32 & $1 \cdot 078$ & 0.28 & 39 & 0.964 & 032 & 71 & $1 \cdot 015$ & $0 \cdot 30$ \\
\hline
\end{tabular}




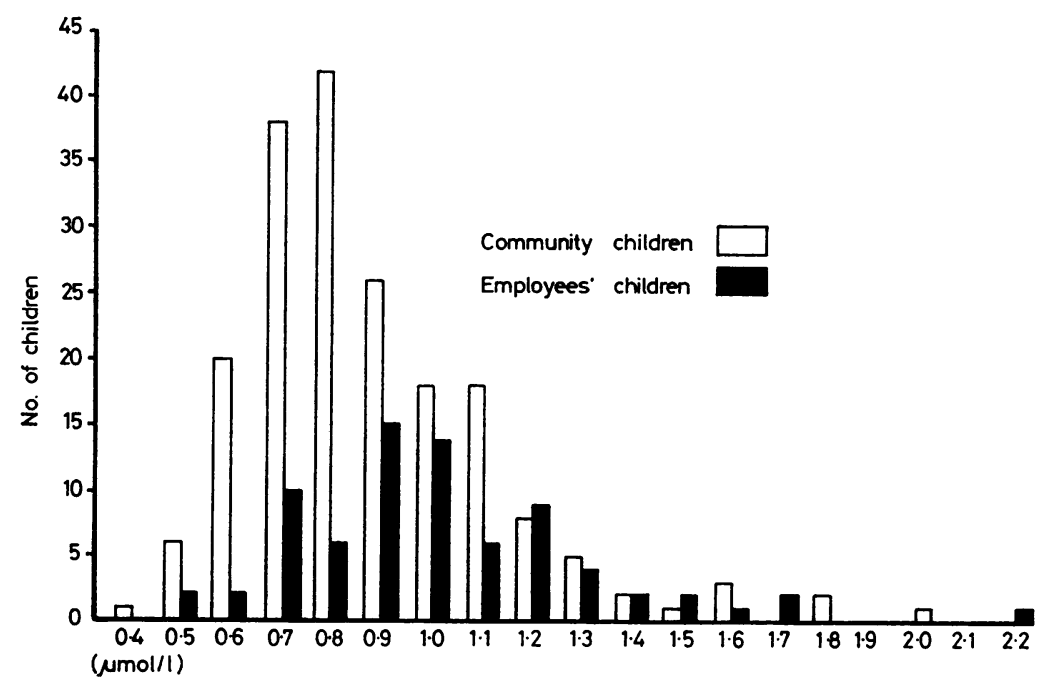

Figure Distribution of blood lead levels.

The results of the various groupings showed some significant differences. The readings and their standard deviations tended to be higher in the younger age groups, and this was significant at ages under 10 (Table 3a). Boys had higher readings than girls in the central as well as in the peripheral parts of the area. The significance of this difference (Table $3 b$ ) is diminished when allowance is made for the average age of all boys $(7 \cdot 8)$ as against that for all girls $(8 \cdot 4)$.

In Tables 4 and 5, the results are set out according to site of residence. Proximity of community children to the lead works was associated with a mean significantly higher $(0 \cdot 13 \mu \mathrm{mol} / \mathrm{l})$ than that for dwellers on the periphery (Table 4). The central area had a higher proportion of younger children, but if the figures are adjusted so as to apply the age distribution of the outer area to the blood lead levels in the central area, it is still significant $(P<0 \cdot 01)$. In a study in the London borough of Tower Hamlets there was also a clear difference between central and peripheral areas (Martin, 1974).
Table 5 Blood lead levels of employees' children by site of residence

\begin{tabular}{llll}
\hline Site & $\begin{array}{l}\text { No. of } \\
\text { children }\end{array}$ & $\begin{array}{l}\text { Mean } \\
\text { umolll }\end{array}$ & $S D$ \\
\hline Central & 1 & $1 \cdot 0$ & - \\
Outer & 14 & $1 \cdot 13$ & 0.45 \\
Elsewhere & 56 & 0.987 & 0.26 \\
All & 71 & 1.015 & 0.30 \\
\hline
\end{tabular}

The warning issued by the Chief Medical Officer in October, 1976, about the use of Bal Jivan Chemco Baby Tonic and the possible use of cosmetics containing lead prompted a separate assessment of Afro-Asian children. There were 12 in the survey, and the mean of the results for them was $1 \cdot 13 \mu \mathrm{mol} / 1$. The prevailing wind towards the eastern half of the survey area was not associated with a higher mean reading in that half; in fact the mean for the eastern half was 0.83 as against $0.94 \mu \mathrm{mol} / 1$ in the western half.

A separate analysis was made of children whose

Table 4 Blood lead levels of community children by the distances of their homes from the lead works

\begin{tabular}{|c|c|c|c|c|c|c|c|c|}
\hline $\begin{array}{l}\text { Age group } \\
\text { (years) }\end{array}$ & $\begin{array}{l}\text { No. living } \\
\text { up to } 280 \mathrm{~m} \\
\text { from works } \\
\text { (central half } \\
\text { of area) }\end{array}$ & $\begin{array}{l}\text { Mean } \\
\text { umolll }\end{array}$ & $S D$ & $\begin{array}{l}\text { No. living } \\
280-400 \mathrm{~m} \\
\text { from works } \\
\text { (outer half } \\
\text { of area) }\end{array}$ & $\begin{array}{l}\text { Mean } \\
\text { umolll }\end{array}$ & $S D$ & $x^{2}$ & $P$ \\
\hline $\begin{array}{r}0-4 \\
5-10 \\
11-16\end{array}$ & $\begin{array}{l}16 \\
36 \\
15\end{array}$ & $\begin{array}{l}1.1 \\
0.986 \\
0.753\end{array}$ & $\begin{array}{l}0 \cdot 37 \\
0 \cdot 29 \\
0 \cdot 12\end{array}$ & $\begin{array}{l}18 \\
70 \\
36\end{array}$ & $\begin{array}{l}0.95 \\
0.841 \\
0.755\end{array}$ & $\begin{array}{l}0 \cdot 24 \\
0 \cdot 19 \\
0 \cdot 22\end{array}$ & $\begin{array}{l}1.4 \\
3.09 \\
-\end{array}$ & $<0 . \overline{01}$ \\
\hline All & 67 & 0.961 & 0.30 & 124 & 0.832 & 0.21 & $3 \cdot 42$ & $<0.001$ \\
\hline
\end{tabular}


blood lead levels were $1 \cdot 3 \mu \mathrm{mol} / 1$ or higher, in view of the use of $25 \mu \mathrm{g} / 100 \mathrm{ml}$ as a cut-off point in a study of 94 children in New York, which suggested that low lead toxicity was a factor in borderline and mild retardation (David et al., 1976). Waldron (1975) also supported a lower value than $1.9 \mu \mathrm{mol} / 1$ to allow for discrimination. In the present survey there were 26 such children, including two with levels just above the normal reference range. These two were the first to be investigated. One was a 'community' girl aged six with a level of $2 \mu \mathrm{mol} / 1$, whose brother, aged four, had a level of $1.8 \mu \mathrm{mol} / 1$. There were full and satisfactory health records for the girl and her brother, and a satisfactory school medical record for the girl. There were no defects and no developmental delay was detected. They lived on a caravan site adjacent to an enclosure used for dumping lead batteries.

The second child, aged three, was the daughter of a works employee living in the periphery of the survey area. Her blood lead level was $2 \cdot 2 \mu \mathrm{mol} / \mathrm{l}$. Her three siblings, aged five, six, and eight, had readings of $1 \cdot 6,1 \cdot 7$, and $1 \cdot 1 \mu \mathrm{mol} / 1$ respectively. Her development had been normal, and a medical examination carried out because of the blood lead result did not reveal anything unusual. The family had formerly lived on the caravan site and the father had once worked as a painter. All the children in both families were referred to a paediatrician who reported favourably.

The mean blood lead level of these 26 children was $1.51 \mu \mathrm{mol} / \mathrm{l}$. The average ages of the 10 boys and 16 girls in this group were, however, lower than those of all boys and girls in the survey by 1.6 and $3 \cdot 2$ years respectively. These lower averages were almost the same for employees' children. A similar mean of $1.52 \mu \mathrm{mol} / 1$ for the 12 employees' children in the group implied that the overall higher mean for this category was largely due to employees' children in the main group of 236 with readings below $1 \cdot 3$ $\mu \mathrm{mol} / \mathrm{l}$. The means for community and employees' children in this main, 'lower level' group were 0.83 and $0.91 \mu \mathrm{mol} / 1$ respectively.

After the families of these two 'borderline' girls had been investigated, information was sought about the remaining 21 children in the group of 26 . The aim was to find out whether they might have had a history of pica or slow development, and to uncover any unusual features such as hyperactivity, retardation of unknown aetiology, use of play material or playgrounds with possible access to lead, or references to paediatricians, psychologists, neurologists, or child guidance clinics. One employee's child aged 12 in the outer half of the area, with a blood lead level of $1.6 \mu \mathrm{mol} / \mathrm{l}$, was said to be hyperactive but otherwise normal. A sibling aged seven with a level of $1.4 \mu \mathrm{mol} / 1$ was a normal healthy child. A community child aged two in the central area, with a blood lead level of $1.4 \mu \mathrm{mol} / 1$, was mentally and physically handicapped, but the twin of this child was normal and had a level of $1 \cdot 1 \stackrel{1}{D}$ $\mu \mathrm{mol} / 1$. Another sibling had a level of $1 \cdot 2 \mu \mathrm{mol} / \mathrm{l}$.

It was possible to re-test seven children originally tested in 1972 whose addresses had not changed. The results for them were very little changed, from 0 a mean equivalent in 1972 of $1.33 \mu \mathrm{mol} / 1$ to 1.27 듬 $\mu \mathrm{mol} / 1$ in 1977 . One child aged seven with the $\overline{\bar{c}}$ highest blood lead level in the 1972 survey (an $\mathbb{\otimes}$ equivalent of $1.8 \mu \mathrm{mol} / \mathrm{l}$ ) had a level of $1.3 \mu \mathrm{mol} / 1$ in 1977, and was normal and healthy. The family ${ }^{\infty}$ had lived at the same address in the central area $\vec{\circ}$ for almost the whole of the mother's life, in a house $\vec{\overrightarrow{ }}$ said to be 100 years old. An evaluation of age of ${ }_{\sigma}^{\omega}$ house and length of residence in the various groups $\overrightarrow{\bar{D}}$ did not reveal any significant differences. Children $\frac{\rho}{3}$ in the oldest houses had a mean level of $0.85 \mu \mathrm{mol} / 1$. $\omega_{N}$ Most of these houses were in the south-west sector, i

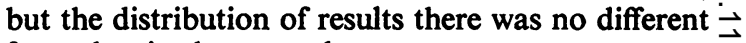
from that in the general survey.

\section{Other areas}

The results have been reported of recent independen blood lead surveys of children under the age of five $\vec{\theta}$ carried out between 1973 and 1975 near Manchestert $\infty$ and Dagenham lead smelting plants manufacturing lead acid batteries. The mean equivalent blood lead 0 levels in Dagenham were $1.04 \mu \mathrm{mol} / 1$ for children living within one mile of the works, $1.05 \mu \mathrm{mol} / 1$ for children living more than one mile from the works, $\frac{\partial}{\not}$ and $1.3 \mu \mathrm{mol} / 1$ for employees' children. (Chloride $\stackrel{\mathbb{Q}}{\square}$ Group Ltd press release, 1975). In Manchester the $\overrightarrow{\overrightarrow{0}}$ equivalent readings were $1 \cdot 32,1 \cdot 29$, and $1 \cdot 6 \mu \mathrm{mol} / 13$ respectively (Elwood et al., 1977). In Tower Hamlets a survey in 1971 showed that $41 \%$ of 39 pre-? schoolchildren living within 400 metres of a lead works had blood lead levels exceeding the equivalent $\stackrel{\circ}{?}$ of $1.94 \mu \mathrm{mol} / \mathrm{l}$, as against $13.7 \%$ of 80 preschoolchildren living in the $400-500$ metre range. The highest levels were found in four of the pre- 8 schoolchildren. Three of them had levels equivalent $₹$ to $3 \cdot 02,3 \cdot 54$, and $3 \cdot 14 \mu \mathrm{mol} / 1$ respectively, lived 응 close to the works, and had fathers working there. The fourth had a level equivalent to $3.62 \mu \mathrm{mol} / \mathrm{l}$, 을 lived in the 400-500 metre range, and showed evidence of pica. (Personal communication, Dr W. C. $/$ Turner, Associate Medical Officer of Health of $N$ Tower Hamlets, 1971; Martin, 1974). A survey స్ల repeated in 1974 showed much improvement. 0 Blood lead levels over $1.45 \mu \mathrm{mol} / 1(30 \mathrm{mg} / 100 \mathrm{ml})$ were found in $22.3 \%$ of the pre-schoolchildren, compared with $56.3 \%$ in 1971 . In Greenwich in 
1976 , this level was exceeded in $16.6 \%$ of the preschoolchildren (including employees' children). The distribution of these results is shown in Table 6. The mean differences between the Tower Hamlets results of 1971 and 1974 for children in all age groups were statistically significant, and the equivalent blood lead levels for preschool and schoolchildren in 1974 were 1.26 and $1.17 \mu \mathrm{mol} / 1$ respectively. (Personal communication, Dr D. H. Raynes, District Community Physician, Tower Hamlets, 1976).

Table 6 Distribution of blood lead levels higher than 1.45 $\mu$ moll 1 by age and sex

\begin{tabular}{llllll}
\hline $\begin{array}{l}\text { Age group } \\
\text { (years) }\end{array}$ & $\begin{array}{l}\text { Community } \\
\text { Boys }\end{array}$ & $\begin{array}{l}\text { children } \\
\text { Girls }\end{array}$ & $\begin{array}{l}\text { Employees' } \\
\text { Boys }\end{array}$ & $\begin{array}{l}\text { children } \\
\text { Girls }\end{array}$ & Total \\
\hline $0-4$ & 3 & 1 & 2 & $1 *$ & 7 \\
$5-10$ & 1 & $1 *$ & 2 & 1 & 5 \\
$11-16$ & 1 & - & - & -1 & 13 \\
All & 5 & 2 & 4 & 2 & 13 \\
\hline
\end{tabular}

* Outside normal reference range

\section{Discussion}

Lead in the environment and experimental work related to it have been discussed by Clayton (1975). In references to mental development, she discounted the interpretation of David et al. (1972) of their findings about high lead concentrations in hyperkinetic children. Bicknell et al. (1968), in a study on pica, explained earlier findings of raised blood lead levels in mentally subnormal children (Moncrieff et al., 1964) by her observations that children with pica were more alike in their current behavioural pattern than in their past history, and that the greater incidence of pica and other behavioural problems in the disturbed, retarded child was likely also to be associated with a raised blood lead level if there was lead in the child's surroundings.

In the Greenwich study there was no reason to think that lead intake from the diet (Ministry of Agriculture, Fisheries and Food, 1972) and the air was other than average or below average. Airborne sampling at about the time of this survey at sites within the area of the survey gave average levels of up to 2 micrograms $\mathrm{Pb} / \mathrm{m}^{3}$, and were reckoned to be within the normal range for an urban area. Below this level, regression lines for such volumetric readings and blood leads were found to be invalid (National Academy of Sciences, Washington DC, 1972) but there was little doubt that they compared favourably with similar areas (Department of Employment, 1972). This level was only moderately exceeded on the edge of the works itself. Results of the biological monitoring of community and employees' children were within a normal distribution, and did not suggest increased intake due to the presence of the lead works. Children with blood lead levels above $1 \cdot 3 \mu \mathrm{mol} / \mathrm{l}$ were normal and healthy. The higher mean for community children living nearest to the works was a finding similar to that of Lansdown et al. (1974), who discovered higher lead levels in children closest to a lead factory. They also found that these levels were unrelated to IQ results or disturbed behaviour; in fact the IQs were somewhat higher and the incidence of disturbed behaviour and hyperactivity was lower in those who had lived their first two years in the polluted area compared with those who had moved into the area. The Greenwich findings also tended to support those of Hebel et al. (1976) on school examination results and lead pollution in Birmingham. The satisfactory results for employees' children obtained in Greenwich were encouraging in view of the anti-pollution and health and safety measures already being taken at the lead works. In a lead works in Vermont, the equivalent levels for employees' children and control children were significantly different at 1.54 and $1.03 \mu \mathrm{mol} / \mathrm{l}$ respectively (Center for Disease Control, 1977b), and at a lead smelter in Memphis where there was a need for chelation therapy in some cases (Baker et al., 1977) work practices may have contributed to the severity.

In the United States Surveillance of Childhood Lead Poisoning, $2 \cdot 7 \%$ of children tested had a blood lead level equivalent to $2 \cdot 4 \mu \mathrm{mol} / 1$ or higher, and more than half of the houses inspected had a lead hazard. (Center for Disease Control, 1977a). It was gratifying to find that in the present survey housing was not identified with hazard.

Advice was given by Needleman (1977) to the Massachusetts legislature on the need to strengthen the Lead Paint Act. He referred to his studies on dental tissue, in which asymptomatic children from areas where lead poisoning was endemic had five times the lead levels of children from non-leaded environments. The tendency in this survey for blood lead levels to be higher in the younger age groups is interesting in view of the highly significant differences found in a Birmingham survey of deciduous teeth; the earlier teeth (incisors) had higher lead concentration, possibly reflecting a higher exposure to lead (Stephens and Waldron, 1976) or a greater physiological uptake in infancy. Equilibrium with the environment is certainly not established in fetal life (National Academy of Sciences, Washington DC, 1972) and may not occur until one to three years of age.

\section{Conclusion}

Biological monitoring of the environment of a lead 
works was repeated after four years, and the blood lead results found encouraging in view of the anti-pollution measures already taken. The findings indicate, as in similar surveys, that raised bloodlead levels are associated with contamination related to employees. Furthermore, the differences in readings between 1972 and 1976 suggest that the practice of good occupational hygiene is an important factor in the prevention of contamination.

I thank all those who helped to carry out this survey, and in particular Mr B. W. Sanderson, District Community Physician, Bexley Health District; Dr M. E. Watts, Specialist in Community Medicine (Child Health), Greenwich and Bexley Area Health Authority; Professor Barbara Clayton and Dr H. T. Delves of the Department of Chemical Pathology, Hospital for Sick Children, Great Ormond Street; and the nurses, technicians, and administrators who dealt with most of the practical work. Much helpful advice was contributed by members of the working party and others, especially Dr C. Ruttle, Dr L. M. Roots, and Dr J. L. Facer of the Department of Health and Social Security; Dr D. Malcolm, Chief Medical Officer, Chloride Group; Dr J. Kerr Brown, Area Medical Officer, Greenwich and Bexley Area Health Authority, who organised the first survey in 1972; and Mr G. B. Allen, Chief Environmental Health Officer, London Borough of Greenwich, who was chairman of the working party.

Reprints from: I. B. Millar, District Community Physician, Greenwich Health District, Morgan Grampian House, Calderwood Street, London SE18 6RB.

\section{References}

Baker, E. L., Folland, D. S., Taylor, T. A., Myron, F., Peterson, W., Loveday, G., Cox, D., Housworth, J., and Landrigan, P. J. (1977). Home contamination with industrial dust. New England Journal of Medicine, 296, 260-261.

Bicknell, J., Clayton, B. E., Delves, H. T. (1968). Lead in mentally retarded children. Journal of Mental Deficiency Research, 12, 282-293.

Center for Disease Control (1977a). Surveillance of childhood lead poisoning-United States. Morbidity and Mortality Weekly Report, 26, 49.

Center for Disease Control (1977b). Increased lead absorption in children of lead workers-Vermont. Morbidity and Mortality Weekly Report, 26, 61-62.
Chloride Group Ltd. (1975). Press release. Chloride Group, 52 Grosvenor Gardens, London SW1.

Clayton, B. E. (1975). Lead: the relation of environment and experimental work. British Medical Bulletin, 31, 236-240.

David, O., Clark, J., and Voeller, K. (1972). Lead and hyperactivity. Lancet, 2, 900-903.

David, O., Hoffman, S., McGann, B., Sverd, J., and Clark, J. (1976). Low lead levels and mental retardation. Lancet, 2, 1376-1379.

Delves, H. T. (1970). A micro-sampling method for the rapid determination of lead in blood by atomic absorption spectrophotometry. Analyst, 95, 431-438.

Department of Employment (1972). Report of the Committee of Enquiry into Lead Poisonings at Avonmouth. HMSO: London.

Elwood, W. J., Clayton, B. E., Cox, R. A., Delves, H. T., King, E., Malcolm, D., Ratcliffe, J. M., and Taylor, J. F. (1977). Lead in human blood and in the environment near a battery factory. British Journal of Preventive and Social Medicine, 31, 154-163.

Hebel, J. R., Kinch, D., and Armstrong, E. (1976). Mental capability of children exposed to lead pollution. British Journal of Preventive and Social Medicine, 30, 170-174.

Lansdown, R. G., Shepherd, J., Clayton, B. E., Delves, H. T., Graham, P. J., and Turner, W. C. O (1974). Blood-lead levels, behaviour and intelligence a population study. Lancet, 1, 538-541.

Martin, A. E. (1974). Epidemiological surveys in the vicinity of lead works. Proceedings of the Royat Society of Medicine, 67, 165-167.

Ministry of Agriculture, Fisheries and Food (1972) Second Report of the Working Party on the Monitoring of Foodstuffs for Heavy Metals. HMSO: London.

Moncrieff, A. A., Koumides, O. P., Clayton, B. E., Patrick, A. D., Renwick, A. G. C., and Roberts, G. E. (1964). Lead poisoning in children. Archives of Disease in Childhood, 39, 1-13.

National Academy of Sciences, Washington DC (1972). National Research Council Committee on Biological Effects of Atmospheric Pollution of Division of Medical Sciences: Airborne Lead in Perspective.

Needleman, H. L. (1977). Paper circulated to Massachusetts legislature and medical personnel. US Department of Health, Education and Welfare: Atlanta, Georgia.

Stephens, R., and Waldron, H. A. (1976). Body burdens of lead in Birmingham. Royal Society of Health Journal, 4, 176-180.

Waldron, H. A. (1975). Subclinical lead poisoning: a preventable disease. Preventive Medicine, 4, 135-153.

Zielhuis, R. L. (1974). Biological quality guide for inorganic lead. International Archives of Occupational and Environmental Health, 32, 103-127. 